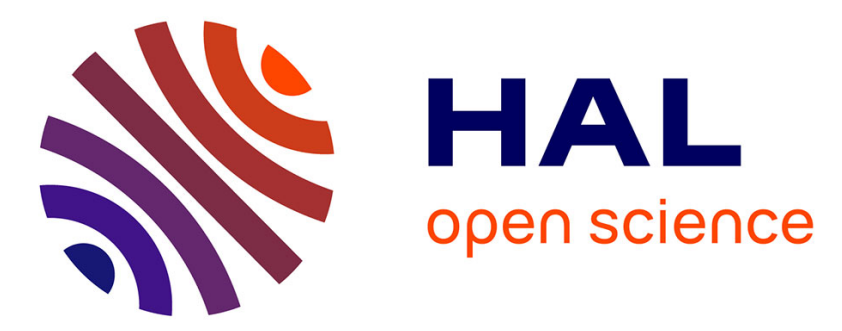

\title{
Farmers' attitudes and landscape change: evidence from the abandonment of terraced cultivations on Lesvos, Greece
}

\author{
Thanasis Kizos, Anastasia Dalaka, Theodora Petanidou
}

\section{To cite this version:}

Thanasis Kizos, Anastasia Dalaka, Theodora Petanidou. Farmers' attitudes and landscape change: evidence from the abandonment of terraced cultivations on Lesvos, Greece. Agriculture and Human Values, 2009, 27 (2), pp.199-212. 10.1007/s10460-009-9206-9 . hal-00535313

\section{HAL Id: hal-00535313 \\ https://hal.science/hal-00535313}

Submitted on 11 Nov 2010

HAL is a multi-disciplinary open access archive for the deposit and dissemination of scientific research documents, whether they are published or not. The documents may come from teaching and research institutions in France or abroad, or from public or private research centers.
L'archive ouverte pluridisciplinaire HAL, est destinée au dépôt et à la diffusion de documents scientifiques de niveau recherche, publiés ou non, émanant des établissements d'enseignement et de recherche français ou étrangers, des laboratoires publics ou privés. 


\title{
Farmers' attitudes and landscape change: evidence from the abandonment of terraced cultivations on Lesvos, Greece
}

\author{
Thanasis Kizos • Anastasia Dalaka • \\ Theodora Petanidou
}

Accepted: 4 December 2008/Published online: 20 March 2009

(C) Springer Science+Business Media B.V. 2009

\begin{abstract}
Agricultural landscapes are the product of the interaction of the natural environment of an area and the practices of its farmers. In this paper, farmers' practices are examined in order to describe and understand processes of landscape change in terraced fields on the island of Lesvos, Greece. We examine the changes of the terraced fields of each farmer and the reasons for these changes, practices concerning the maintenance of terraces and how farmers view this landscape change. The concept of farming systems is used to link farmers' practices at the farm level with changes at the landscape level. Data come from research via questionnaires to farmers in order to record their practices, to explore changes in land use and the landscape elements and the reasons behind these changes, and finally to record their opinions on the landscape change that result. Findings indicate that although farm households in the case study areas depend on farming incomes by very different degrees, they employ similar cultivation and landscape management practices. At the same time, "hobby" farm households may be more prone to abandonment of fields and negligence of landscape elements (here terraces).
\end{abstract}

Keywords Cultivation terraces - Landscape change · Olive plantations · Lesvos Island · Greece

\section{Introduction: farmers' practices and landscape change}

The agricultural landscape of an area is the product of the interaction of the natural environment with the practices of

T. Kizos $(\bowtie) \cdot$ A. Dalaka $\cdot$ T. Petanidou

Department of Geography, University of the Aegean, University

Hill, 81100 Mytilini, Greece

e-mail: akizos@aegean.gr the farmers of the area (Farina 2006). Farming systems are reflected upon the landscape, and different practices shape complex landscape mosaics with significant differences even for the same land uses.

Farming systems are complex systems of attitudes, implicit rules, knowledge, experiences, etc., in a specific area, which describe the ways farming is practiced (Van der Ploeg 1992). These farming practices shape the appearance of farms, the architecture of farming constructions, and the social distribution of labor in and among farms. Therefore, they represent similarities in farming "profiles" in an area, imprinting linkages between economic, social, technological, ecological, and political dimensions upon the landscape (Van der Ploeg 1992). With the use of farming systems the structure of farms (cultivated area, animals, land uses) and the type of practices are grouped in the specific area, and this allows the analysis of practices at the landscape level and not at the level of individual farms.

We use the term "landscapes" in this paper into two different scales: farm-level landscapes that are shaped by the practices of individual farm households and largerscale landscapes (i.e., that of a locality with discernable geophysical or cultural limits or a regional scale) that are the sum of the farm-level ones. Landscapes change continuously. By landscape change, we refer to differences in function and form of a landscape over time. Changes differ spatially and temporally. Spatially, along increasing or decreasing scales certain details and landscape elements "appear" or "disappear," and linkages and networks between these elements may have different functions and forms according to scale (Farina 2006). Such an example is cultivation terraces: at the small scale (i.e., that of the field) they are very much "visible" and functional parts of the landscape, while at the large scale (e.g., that of the 
Mediterranean) they "disappear," as landscape types are usually defined by land cover or land use. Temporal scales are equally important, as different driving forces act upon landscapes in scales varying from days to millennia (Marcucci 2000).

In this study, we focus on short-term processes (months or years up to decades) and actions of the farmers at the farm level for analyzing broader landscape change (examples in the literature include Kristensen 1999; Busck 2002; Kristensen et al. 2004; Quetier et al. 2005). Smallscale research is vital for conceptualizing the processes that change agricultural landscapes. At the same time, the summing up of all these small-scale changes requires the use of larger scales for understanding the whole landscape and the relationships between its elements. These actions at the farm level include all management practices: the type and intensity of energy inputs, the land cover (land use and their changes and the alteration of landscape elements including farm infrastructure). Farming systems group these actions at the landscape level.

Cultivation terraces are a special landscape element found around the world (Netting 1993; Grove and Rackham 2002). They are an artificial, level surface used for cultivation on sloppy terrain, in the Mediterranean usually supported by a stone wall (Petanidou et al. 2008) and sustaining a variety of different land uses. In the Mediterranean of the twentieth century, terraced olive plantations and vineyards were not abandoned to the degree terraced arable cultivations were. This is because permanent plantations such as olives and vines represent a significant investment in time and money and they can still provide products of high value and domestic consumption. Arable cultivations on the contrary, were progressively abandoned in favor of the easy-to-cultivate lowlands (Grenon and Batisse 1989).

Land use and landscape change at the farm scale is a process driven by many different factors, some related to the economic efficiency of the specific land uses and/or the farms and others related to social issues. Relevant research in areas around the globe where cultivation terraces are found reveal some common threads in otherwise different settings.

In China and Eastern Asia, fundamental changes take place for cultivation, particularly on terraces. Fu et al. (2006) evaluate land use and landscape change in relation with farmer practices and broader socioeconomic changes that put farming at a disadvantage economically. Ostwald and Chen (2006) and Long et al. (2007) link policies and land use decisions of small farmers with broader socioeconomic driving forces of recent but very important land use changes. Rao and Pant (2001) analyze land use and landscape change that includes terraces in India in regard to farmers' practices and decisions in response to policies and socioeconomic changes. In all these different contexts, terraces are not maintained as older land use systems change and the cultivation that were supported by these terraces are either abandoned or change according to (usually extra-local and international) market needs.

In the Mediterranean, Olarieta et al. (2008) present an example in Spain of land use change decisions and soil preservation practices, including terraces that bear similarities with the case study discussed here, as terraces are not maintained due to the abandonment of older land uses in favor of housing and Mediterranean forest. Another similar Spanish example is offered by Gallart et al. (1994). Around the Mediterranean, Varisco (1991) discusses a similar example in Yemen, where small farmers find it hard to cope with broader social and economic changes and seek a way out of "traditional" farming, including cultivation on terraces. Particularly in Greece, Bakker et al. (2005) link on Lesvos the intensity and the type of land use change with the physical characteristics of the landscape (geology, relief, slope gradient), and relate specific land uses with soil erosion rates that in turn cause further land use changes. Terraces are central in their description, as most land use changes take place on terraced land. Hill et al. (1998) monitor the impacts of grazing on the island of Crete and discuss the policy and socioeconomic driving forces of grazing pressure increase. Petanidou et al. (2008) discuss a similar case with the one presented here on another Aegean Island, Nisyros, and conceptualize social and economic factors as the key driving forces behind the almost complete cultivation abandonment and landscape change, including the collapse of terraces.

The most complete accounts for the Mediterranean of the role of cultivation on terraces and the reasons that it is abandoned in a historical perspective are offered by Blanchemanche (1990) and Grove and Rackham (2002). These authors offer examples of terraces styles and functions from all European Mediterranean countries and discuss at length the causes and consequences of their neglect. For the rest of the globe, Netting (1993) provides insights to many different settings, in some cases for terraces.

All these approaches and researches, despite different and diverging foci, suggest that land use change alters landscape elements and characteristics even as it may support former land uses. In most if not all cases, the role of farmers and their decisions is the key development; these decisions are responses to specific policies and to general socioeconomic changes that usually include some form of intensification of agricultural practices that is costly or simply impossible where terraces are present. They may also include a general shift from farming to other sectors of the economy and rural exodus towards proximate or distant urban centers. If the driving forces behind these changes could be conceptualized in a chain of "proximity" 
for farmers, then these socioeconomic changes are the most "distant" compared to policies, for example, or market changes for their products, but also ultimately may prove stronger than policies and market fluctuations. This appears to be a global trend with varying intensity.

The link between these different scales can be provided by the use of farming systems. Farming systems group together individual farmers' practices and allow the mapping of these practices on the landscape. In this paper, farmers' practices are examined in order to understand and describe processes of landscape change in terraced fields on the island of Lesvos, Greece, and present some of the most important features of this landscape under different farming strategies.

\section{Cultivation on terraces on Lesvos}

Lesvos is the 3rd largest island in the Aegean $\left(1632.8 \mathrm{~km}^{2}\right.$ ), with a population of ca. 90,000 (in 2001, $40 \%$ in Mytilini, the capital). The number of farms has significantly reduced recently (20\% from 1971 to 2001), but agriculture is still quite important in terms of the jobs and incomes it provides, especially in rural areas. The most important agricultural land uses consist of olive plantations and grazing lands (for sheep). Spatially (Fig. 1), the olive plantations are mainly located in the eastern part of the island and grazing lands in the western (Dalaka and Petanidou 2006). The olive plantations constitute in their greatest part a homogenous landscape, very characteristic for Lesvos and part of its local identity, with most trees lying on small, hilly or mountainous and sloping fields. The olive plantations lying on slopes greater than $10-15 \%$ are all terraced, either in pocket type (a single terrace in part of a circle around one tree), in parallel-braided type, or often in mixed types (Dalaka and Petanidou 2006). The understory of olive plantations is very rarely cultivated with arable crops and today it is often not even grazed.

The significance of olive cultivation rose rapidly after the 18th century (Kizos and Koulouri 2006). The twentieth century brought economic crisis and the beginning of the rural exodus that accelerated after the 1940s (leading to a population decline of $35 \%$ between 1940 and 1981). This migration resulted in a significant decline of most land uses other than olive plantations since the 1930s. The significance of grazing lands has increased at the same time, replacing abandoned arable land in sloping areas (cereals, pulses, and tobacco). In 2001, the agricultural census recorded 14,375 olive farms $(95 \%$ of the total farms recorded on the island) covering $45 \%$ (38,951.8 ha) of the total Utilized Agricultural Area (UAA) and roughly $30 \%$ of the total area of the island, and 3,723 farms with grazing lands (23\% of total farms) covering $49.5 \%$ of the UAA, grazed by roughly 300,000 sheep and 44,000 goats (along with 7,000 cows). The total number of olive trees is estimated by subsidies data at 10.5-11 million, while estimations by satellite images (Thomaidou and Koutsobilis 2004) raise the number to roughly eight million trees (density of 182 trees/ha against 250-280 trees/ha with the former estimation).

Regarding the different types of olive plantations that are encountered on the island, Kizos and Koulouri (forthcoming) modify the typology developed by the OLIVERO project (see the special issue edited by Fleskens and Graaff 2008 and especially Stroosnijder et al. 2008, p. 80) and distinguish four different types of olive plantations: (A) Low-input traditional plantations (40-250 trees per ha) typically planted on terraces, managed with few or no chemical inputs, limited irrigation, with high labor input; (B) Neglected plantations, in between cultivation and abandonment, in which little other management is practiced besides collecting olives; (C) Abandoned plantations that are former olive fields without cultivation and without harvest for a number of years and scrub or pines or oak and maquis growth; and (D) Housing plantations, which are former olive fields where one or more buildings are found (houses, holiday homes, tourism units, manufacture or commerce constructions). Schematic depictions of these four landscapes are given in Fig. 2I, while in Fig. 2II the changes of olive trees with abandonment of cultivation practices are depicted and in Fig. 2III different types of terraced olive plantations are depicted, all encountered on Lesvos. This typology represents a considerable simplification of real conditions but each type represents different production systems and different small-scale landscapes. Changes between these types are continuous, as cultivated or abandoned fields are cleared for housing, fields are abandoned or neglected, and abandoned or neglected fields are cleared for cultivation. The only irreversible change is clearing a field for housing and removing trees and other existing characteristics (terraces, storage buildings, stone walls, etc.).

For grazing lands only two different landscapes are encountered (Fig. 3): (A) Cultivated arable fields on terraces, sown with cereals in systems combined with fallow and grazing or with mixed cultivation with legumes; and (B) Former arable fields turned into grazing land for sheep, in which the terraces are degraded and non-edible for sheep scrub and bare ground appear. Schematic depictions of these landscapes are given in Fig. 2. Again, this typology represents a simplification of real conditions but here changes have taken place only from landscape (A) to (B) and not vice versa.

In this paper, the case of cultivations on terraces on Lesvos Island is examined in order to describe and understand processes of landscape change in micro scale, 
Fig. 1 Location of the case study settlements on the island of Lesvos

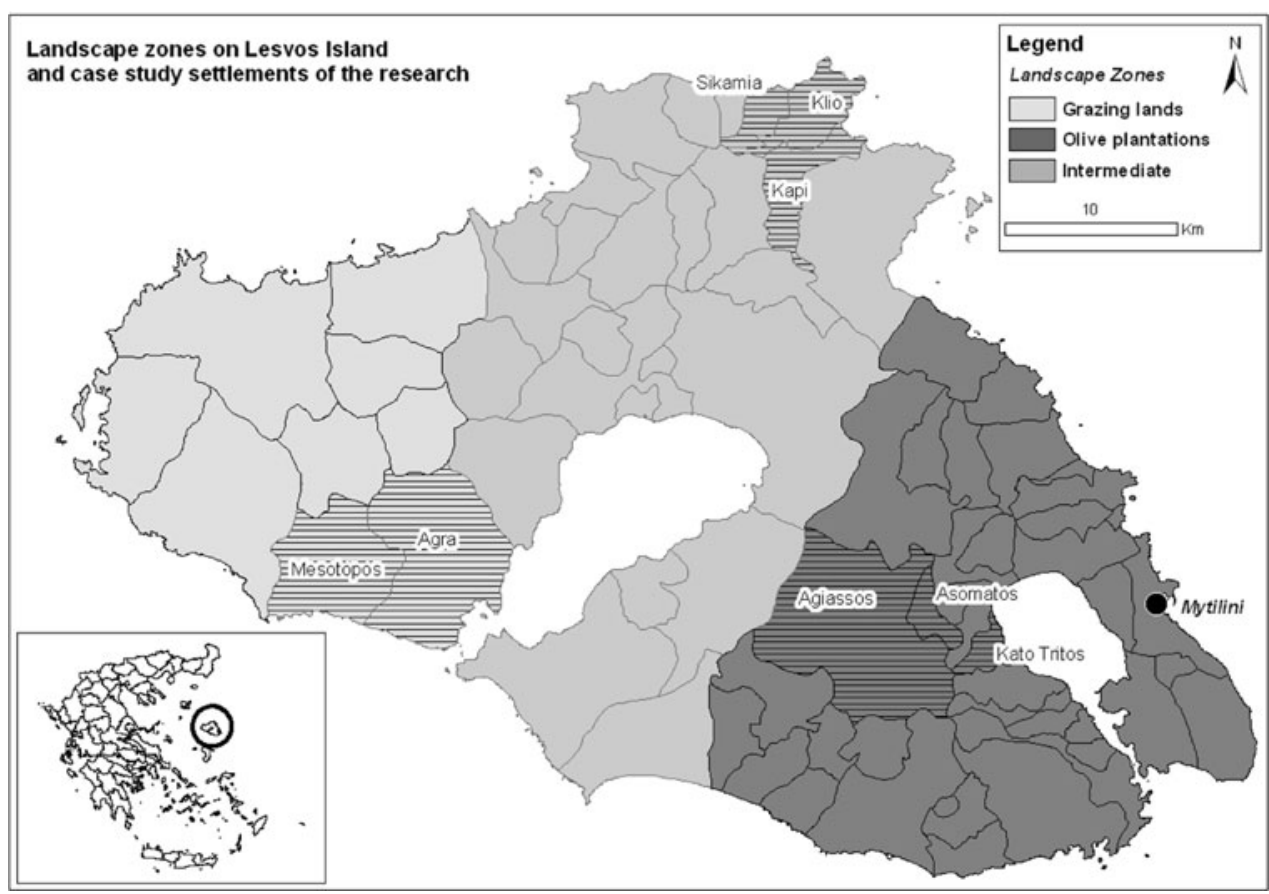

that of farmers and their practices. The particular landscape was shaped with practices of high environmental value (Van-Camp et al. 2004) (e.g., construction and maintenance of terraces, natural fertilizing and pesticides control, pruning, etc.) that were gradually abandoned after the 1950s. As to the research objectives, we examine when the abandonment of the terraced fields of each farmer took place and for what reasons; what types of land uses were abandoned first or later and why; practices concerning the maintenance of terraces; a number of issues concerning how farmers view this landscape change and especially the "value" of cultivation terraces; and finally the relation of these landscape changes to different farming styles.

\section{Methods and data}

In the conceptual frame of our approach, the abandonment of fields on terraces is considered as a result of socioeconomic processes that make cultivation less attractive and either forces people out of the area or makes them seek off farm occupations. Abandonment in its turn causes land use changes that alter the landscape elements, one of which are terraces (other such elements include stonewalls that separate fields and farm buildings build with stone). Terraces can be built or maintained by farmers themselves, but usually they involve the work of local craftsmen and therefore are prone to negligence when the fields are abandoned or even if the fields are cultivated but farmers view their maintenance as a purposeless financial burden.
Here, we use data acquired via personal interviews with farmers in selected settlements of the island with the use of a semi-structured questionnaire in four sections: (1) farmers and their households; (2) farms and the cultivation practices with a focus on cultivation terraces; (3) land use changes and impact on terraces; and (4) opinions and views of farmers. For the first section, on- and off-farm employment of the members of the households and their incomes from on- and off-farm sources were recorded (in six classes: <1500€, 1500-3000€, 3000-6000€, 6000$9000 €, 9000-12000 €$, and $>12000 €)$. For the second section, the types of land use on terraces and the practices per land use were recorded along with the quality of terraces across a five-value scale (from collapsed to very good quality, of relative reliability only). In the third section, land use changes on terraces were recorded. Farms on Lesvos, as everywhere in Greece, are dispersed in many fields (six on average according to the 2001 census), which may be located at significant distances. Therefore, farmers may abandon one field and still cultivate others. Land use changes on terraces were recorded as discrete incident per field and farm, resulting in as many as three different changes per farm, i.e., in one farm three different fields had changed use. We examine also the time period when abandonment took place and the reasons behind such decisions.

The selection of the case study settlements was based on geo-climatic conditions (Dalaka and Petanidou 2006) and land use (Kizos and Spilanis 2004) according to which the island is divided into three zones: the eastern $(\mathrm{E})$, covered 
Fig. 2 I Four schematic landscapes of olive plantations on Lesvos. (A) Low-input traditional plantation on pocket terraces with pruned trees and cleared understory. (B)

Neglected plantation with nonpruned trees and growth of understory scrub and bushes (olives may be harvested). (C) Abandoned plantation with trees that have "turned wild" and bushes and trees in the understory forming a dense forest. (D) Housing plantation, where almost all olives and all terraces are removed and new tree species are planted. II Three stages of olive tree appearance with abandonment of cultivation practices. (A) pruned and harvested tree with few and low branches. (B) Neglected tree with branch growth vertically and horizontally and growth of "wild" branches low on the trunk or the roots (may still be harvested). (C) Abandoned tree, "turned wild" with branch growth all over the trunk, less foliage, smaller new leaves, and bush-like appearance. III Three schematic landscapes of lowinput traditional terraced olive plantations on Lesvos. (A) Plantation on parallel terraces with large spaces between terraces. (B) Plantation on parallel terraces with large spaces between terraces and with pocket terraces in between. (C) Plantation on pocket terraces (drawing by the authors)
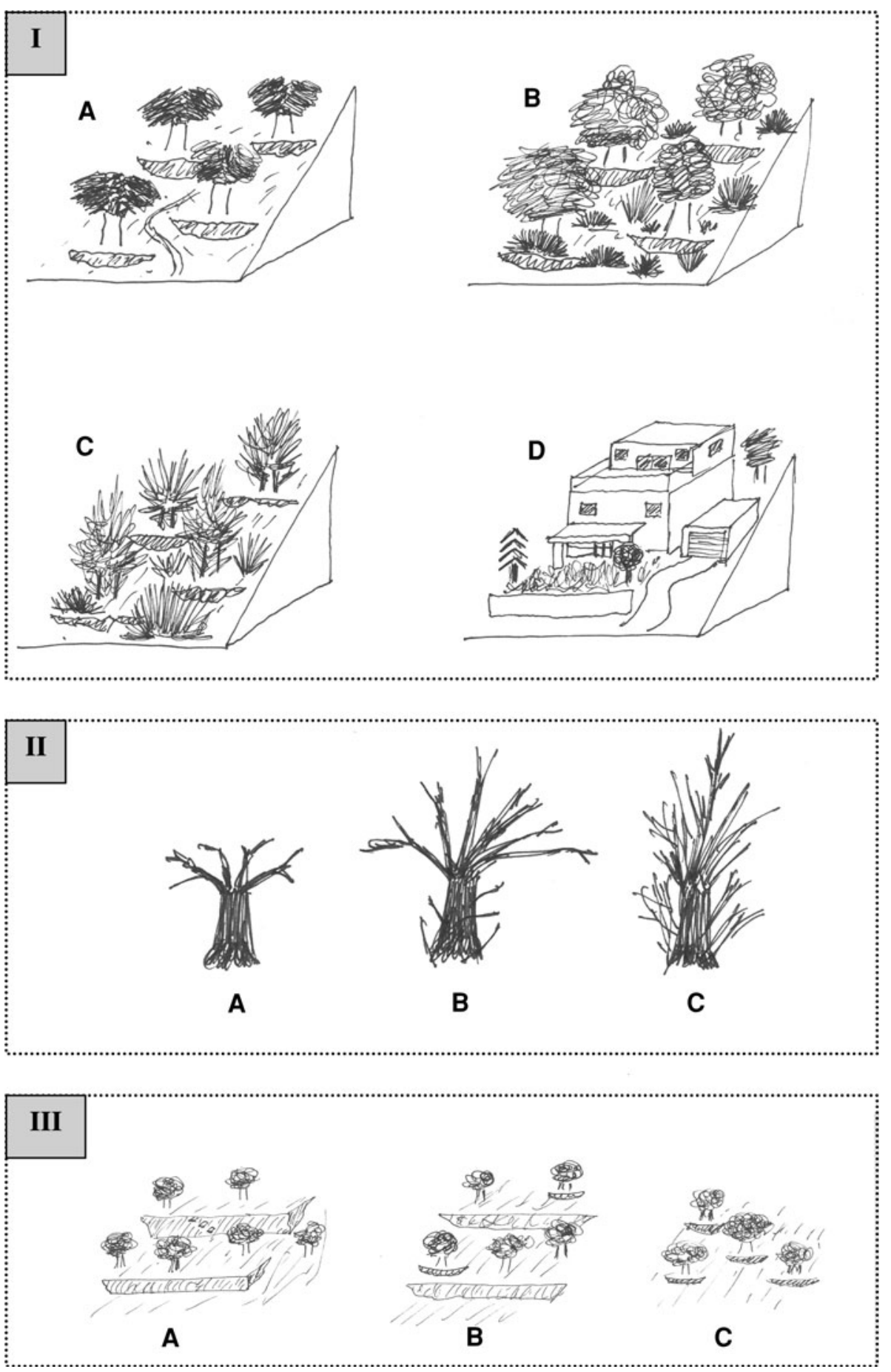

mainly by olive plantations, and the intermediate central (C) and the western (W), dominated by grazing lands. Two or more nearby settlements were selected from each zone: Asomatos, Agiassos, and Kato Tritos for zone E; Klio, Sikamia, and Kapi for zone C and Agra and Mesotopos for zone W (Fig. 1). The sample was selected in each settlement according to the available respondents in the particular settlements at the time of the visits. By available respondents we refer to the part of the total population of farmers that was present in each village at the time of the visits. In addition, three ex-farmers were also included, as their own experiences and views were considered important for the research. This strategy resulted in an aged sample, according to what the census of 2001 recorded 
Fig. 3 Two schematic landscapes of grazing lands on Lesvos. (A) Cultivated traditional arable field on terraces, sown with cereals. (B) Former arable field turned into grazing land for sheep with terraces degraded and appearance of non-edible scrub and bare ground (drawing by the authors)
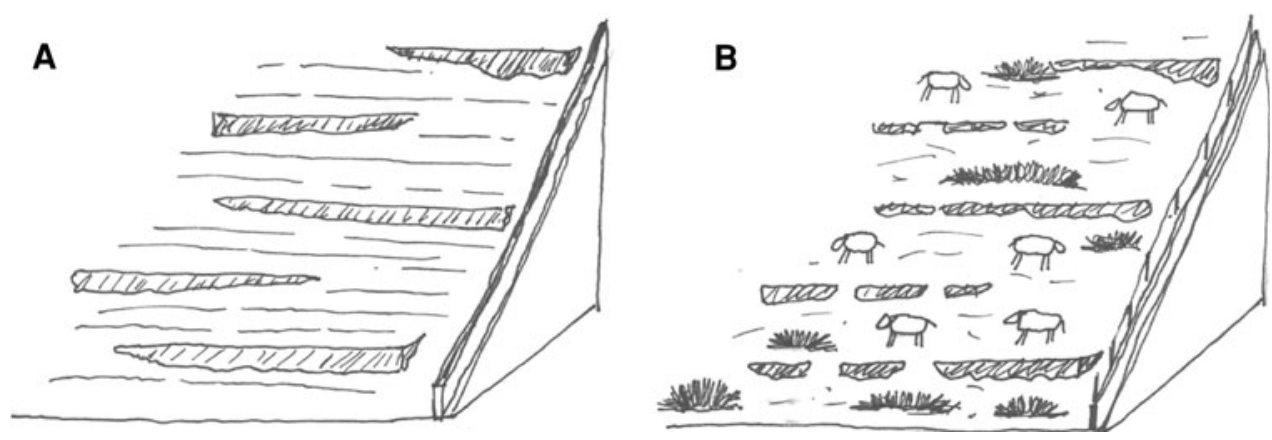

(Table 1), as in all but one settlement the average age of the respondents was over 60 years. ${ }^{1}$ Respondents explained this by claiming that many young and middle aged farmers (and generally inhabitants) may have been recorded as inhabitants (and farmers) of the particular settlement, but in reality live elsewhere and mostly in the island capital town, where more jobs are available. Our own observations during visits agreed with this explanation. This is something that is not rare in rural areas of Greece as many outmigrants who live today in urban areas still maintain close ties with their "homelands," keep houses there, keep farms, often visit, vote there, and are recorded there during the population census (see Damianakos 2002 for more examples and discussion). Therefore, what may seemed like a bias of the sample towards aged farmers was probably more representative of the actual situation of the settlements and in any case this bias is not necessarily negative, as the practices and views of exactly these farmers can answer the type of questions this paper addresses. In total, 103 interviews were made in the Fall of 2004-Winter 2005 (Table 1).

\section{Findings of the research}

Farmers and farms

\section{Farmers, households, and incomes}

Farmers in the sample were mostly men (only $10 \%$ were women) and aged ( $8 \%$ were younger than 40$)$. Their age is reflected in the size of their households as well, with $51 \%$ being two person households (aged couples) and 12\% one person households (mostly elder widows or widowers).

Regarding occupation and income, $72 \%$ of the respondents declared that they work in the farm and $78 \%$ that they have farming incomes. Of the rest, $74 \%$ were older than

\footnotetext{
1 The agricultural census of 2001 does not provide average age of farmers but only the frequencies of age groups for each settlement. In some settlements, as much as $56 \%$ of the total number of farmers are older than 65 (Asomatos) and only in the settlements of the Western zone is the percentage of aged farmers lower than $20 \%$ (Table 1).
}

60 years and had abandoned farming almost completely. The majority of the respondents $(77.6 \%)$ declared off-farm incomes, most $(70 \%)$ from pensions, the rest from services (private $26.5 \%$ and public $3.5 \%$ ). There were no significant differences between the different zones.

Farm incomes were in general low (lower than 3,000€ for $61.3 \%$ of the sample). Family incomes were higher (higher than $9,000 €$ for $43 \%$ of the respondents) and positively correlated with farm income (Spearman's $r=0.272, \quad p=0.015, \quad N=79$ ). By categorizing the degrees of difference for farm and family income classes, three groups of farm households were created: "professional," "semi-professional," and "hobby." A small proportion (14.5\%, 15 households) had the same farm and family income class (e.g., farm income in the 3000-6000€ class and family income in the same class) and most if not all of their family incomes came from farming; therefore they can be regarded as "professional" farm households. The majority $(44.7 \%, 46$ households) had one class difference in favor of family income (most of it coming from farming) and can be regarded as "semi-professional" farm households. The rest $40.8 \%$ (42 households) had a two or three classes difference in favor of family income and can be regarded as "hobby" farm households, with only a part of their family incomes coming from farming or declaring no farming incomes at all.

None of the farmers of "professional" households were older than 63 (average age 53 years against 63 for the "semi-professionals" and 67 for "hobby"). As expected, farmers of "professional" farm households were active and worked in their farms more often. Differences among zones and settlements were evident but not statistically significant: most of the "professionals" were encountered in the intermediate zone and most of the "hobby" in the grazing lands zone.

\section{Land uses, farm characteristics, and farming systems}

According to the agricultural census, farms in the western zone of the island are larger. On the contrary, farms in the other two areas are small and close to the national average farm size (i.e., 4.4 ha). One of the most important 
Table 1 Number of questionnaires per settlement and data on the population and the farmers of the settlements

\begin{tabular}{|c|c|c|c|c|c|c|}
\hline Settlement & $\begin{array}{l}\text { Number of } \\
\text { respondents } \\
\text { (total }=103 \text { ) } \\
1\end{array}$ & $\begin{array}{l}\text { Average age } \\
\text { of the respondents } \\
\text { in the sample } \\
2\end{array}$ & $\begin{array}{l}\text { Population } \\
2001 \\
3\end{array}$ & $\begin{array}{l}\text { Population change } \\
1991-2001(\%) \\
4\end{array}$ & $\begin{array}{l}\text { Number } \\
\text { of farmers } \\
5\end{array}$ & $\begin{array}{l}\text { Percentage of } \\
\text { farmers }>65 \text { years } \\
6\end{array}$ \\
\hline \multicolumn{7}{|l|}{ Western zone } \\
\hline Agra & 17 & 57.4 & 1030 & -1.8 & 204 & 18.1 \\
\hline Mesotopos & 18 & 63.0 & 1039 & 3.4 & 203 & 18.2 \\
\hline \multicolumn{7}{|l|}{ Eastern zone } \\
\hline Asomatos & 11 & 63.5 & 328 & -17.5 & 106 & 56.6 \\
\hline Agiassos & 13 & 66.2 & 2587 & -13.4 & 841 & 44.9 \\
\hline Kato Tritos & 8 & 63.7 & 767 & -11.3 & 180 & 27.2 \\
\hline \multicolumn{7}{|l|}{ Central zone } \\
\hline Klio & 19 & 60.0 & 592 & 2.1 & 165 & 52.1 \\
\hline Kapi & 13 & 64.0 & 654 & -9.4 & 200 & 39.5 \\
\hline Sikamia & 4 & 68.2 & 371 & -13.0 & 84 & 30.9 \\
\hline Total (Island of Lesvos) & & & 90643 & 3.9 & 16006 & 35.7 \\
\hline
\end{tabular}

Source: (1) and (2)—authors' research; (3), (4), (5), and (6)—ESYE (2003)

characteristics of the farms is the large average number of field plots per farm and the small average field size, with the exception of farms in the western part (Table 2). For olive plantations, this is expected up to a point, considering their value and the will of parents to provide their offspring with at least one plot. Nevertheless, this is an extra labor and financial burden for farmers, to have to cultivate many small fields, usually at significant distances.

In the sample of our study (Table 3), $86.4 \%$ of the farms had olive plantations of 4.3 ha average size. Grazing lands, declared by the $37 \%$ of the farmers (most in the western zone as expected), were larger (13.7 ha per farm), while tree fields, arable and garden crops fields, and vineyards were very small $(2.1,1.4,0.37$, and 0.3 ha per farm respectively). Most of these areas were owned by the respondents and only $11 \%$ of them rented more plots, mostly olives. Animal husbandry for farms of the sample concerned almost exclusively sheep and goats and has declined in the last decade (49\% of the farms reported animals, $19 \%$ less than 10 years ago). On the contrary, the average size of animals per farm had increased (from 57 to 98 animals per farm). The size of olive plantations of "professionals" was higher on average from the other two groups (Table 3) and so is the percentage of farms with

Table 2 Farm statistics per settlement

\begin{tabular}{lllllllll}
\hline & $\begin{array}{l}\text { Average } \\
\text { farm size } \\
\text { (ha) }\end{array}$ & $\begin{array}{l}\text { Number } \\
\text { of fields/ } \\
\text { farm }\end{array}$ & $\begin{array}{l}\text { Average } \\
\text { field size } \\
\text { (ha) }\end{array}$ & $\begin{array}{l}\text { Farms } \\
\text { with tree }_{\text {crops }^{\mathrm{a}}}\end{array}$ & $\begin{array}{l}\text { Farms with tree } \\
\text { crops of total } \\
\text { farms } \%)\end{array}$ & $\begin{array}{l}\text { Farms with } \\
\text { tree crops } \\
\text { average } \\
\text { size (ha) }\end{array}$ & $\begin{array}{l}\text { Farms with } \\
\text { grazing } \\
\text { lands }\end{array}$ & $\begin{array}{l}\text { Farms with } \\
\text { grazing lands of } \\
\text { total farms }(\%)\end{array}$ \\
\hline $\begin{array}{l}\text { Lesvos prefecture } \\
\text { Western zone }\end{array}$ & 6.6 & 6.0 & 1.1 & 15341 & 84.6 & 2.7 & 4727 & 26.1 \\
average size \\
Agra
\end{tabular}

Source: ESYE (2003)

${ }^{a}$ Data for olive plantations are not available, but on average $97 \%$ of the tree crops are olive plantations 
Table 3 Number and size of land uses of farms of the sample per farm household groups and per land use zone

\begin{tabular}{|c|c|c|c|c|c|c|c|c|}
\hline $\begin{array}{l}\text { Farm household } \\
\text { groups/zone of } \\
\text { island }\end{array}$ & $N$ & $\%$ & $\begin{array}{l}\text { Farms with olive } \\
\text { plantations to total } \\
\text { farms }(\%)\end{array}$ & $\begin{array}{l}\text { Average olive } \\
\text { plantation size per } \\
\text { farm (ha) }\end{array}$ & $\begin{array}{l}\text { Farms with } \\
\text { grazing lands to } \\
\text { total farms }(\%)\end{array}$ & $\begin{array}{l}\text { Average grazing } \\
\text { land size per } \\
\text { farm (ha) }\end{array}$ & $\begin{array}{l}\text { Farms with sheep } \\
\text { and goats to total } \\
\text { farms }(\%)\end{array}$ & $\begin{array}{l}\text { Sheep and } \\
\text { goats per } \\
\text { farm }\end{array}$ \\
\hline Professionals & 15 & 14.5 & 86.7 & 5.7 & 26.6 & 18.0 & 73.3 & 143 \\
\hline $\begin{array}{l}\text { Semi- } \\
\text { professionals }\end{array}$ & 46 & 44.7 & 91.3 & 4.0 & 34.7 & 11.9 & 43.5 & 105 \\
\hline Hobby & 42 & 40.8 & 80.9 & 4.0 & 45.2 & 14.3 & 47.6 & 66 \\
\hline Eastern zone & 32 & 31.0 & 100.0 & 5.7 & 3.1 & 1.0 & 15.6 & 11 \\
\hline Western zone & 35 & 34.0 & 60.0 & 1.9 & 88.6 & 16.3 & 65.7 & 122 \\
\hline Central zone & 36 & 35.0 & 100.0 & 4.4 & 19.4 & 3.8 & 63.8 & 92 \\
\hline Total & 103 & 100 & 86.4 & 4.3 & 37.9 & 13.7 & 49.5 & 98 \\
\hline
\end{tabular}

Source: Authors' research findings and calculations

sheep and goats and the number of sheep and goats per farm (Table 3).

Regarding cultivation practices on terraced fields, eight were recorded in olive plantations (Table 4): picking the olives and pruning were reported by almost all farm households which answered this question (9\% of the farms did not report their practices). Ploughing of the understory, fertilization, plant diseases protection, irrigation, harvesting of the understory grasses, and mixed cultivation (growing arable crops in the understory) were reported in decreasing order. The combinations were many and complex, with the most common (e.g., picking the olives, pruning and plowing of the understory) practiced by the $13.6 \%$ of the farm households, while only $6.1 \%$ practiced just picking and pruning. Finally, $14.4 \%$ reported organic olive plantations the presence of which was not related with farmer or farm characteristics, neither was the use of machinery (tractors for $18 \%$ of the total number of farms or digging equipment for $32 \%$ ).

The combinations reveal that all olive farm households were active in terms of cultivation practices on at least one of their fields, but also that the limited set of practices available yielded many different cultivation styles. The different practices and the combinations were not related to the characteristics of farmers or the group of farm households, showing that even "hobby" ones can be actively employing many of these practices and complex combinations (i.e., more "hobby" farms plough the understory and use plant protection than "professional" ones, Table 4). It is true that the cultivation of olive plantations assists all types of farmers to be active, with their relative limited cultivation requirements, but again the fact is revealing of how complex the reality of farmers and farm households really is. Another important issue is that many farm households use workers (usually immigrants) for some of these practices, a common practice in Greece in the last decades. These combinations indicate that in most farms the "low-input traditional plantations" landscape was encountered, at least in the fields that were still cultivated. Concluding, it seems that in terms of practices the use of farm groups does not correspond to discrete farming systems or different landscapes at field level. There were

Table 4 Cultivation practices on terraced olive plantations for farm household groups of the sample and land use zones

\begin{tabular}{|c|c|c|c|c|c|c|c|}
\hline & \multicolumn{3}{|c|}{ Farm household groups } & \multicolumn{3}{|c|}{ Zone of the island } & \multirow[t]{2}{*}{ Total } \\
\hline & Professionals & $\begin{array}{l}\text { Semi- } \\
\text { professionals }\end{array}$ & Hobby & $\begin{array}{l}\text { Eastern } \\
\text { (olives) }\end{array}$ & $\begin{array}{l}\text { Western (grazing } \\
\text { lands) }\end{array}$ & $\begin{array}{l}\text { Central } \\
\text { (intermediate) }\end{array}$ & \\
\hline $\begin{array}{l}\text { Total number of farms with terraced olive } \\
\text { plantations }\end{array}$ & 13 & 38 & 32 & 32 & 15 & 36 & 83 \\
\hline Picking olives & 100.0 & 100.0 & 93.8 & 93.8 & 100.0 & 100.0 & 97.6 \\
\hline Pruning & 100.0 & 100.0 & 93.8 & 93.8 & 100.0 & 97.2 & 96.4 \\
\hline Ploughing of understory & 53.8 & 65.8 & 75.0 & 62.5 & 80.0 & 66.7 & 67.5 \\
\hline Fertilization & 53.8 & 55.3 & 50.0 & 53.1 & 46.7 & 55.6 & 53.0 \\
\hline Plant diseases protection & 38.5 & 52.6 & 46.9 & 71.9 & 40.0 & 30.6 & 48.2 \\
\hline Irrigation & 53.8 & 34.2 & 31.3 & 15.6 & 60.0 & 44.4 & 36.1 \\
\hline Harvesting understory grasses & 38.5 & 10.5 & 21.9 & 15.6 & 26.7 & 19.4 & 19.3 \\
\hline Mixed cultivation & 0.0 & 5.3 & 3.1 & 6.3 & 6.7 & 0.0 & 3.6 \\
\hline
\end{tabular}

Source: Authors' research findings and calculations 
Table 5 Terraced land uses of the farms of the sample for land use zone
Source: Authors' research findings and calculations

\begin{tabular}{|c|c|c|c|c|}
\hline & Eastern (olives) & $\begin{array}{l}\text { Western } \\
\text { (grazing lands) }\end{array}$ & $\begin{array}{l}\text { Central } \\
\text { (inter-mediate) }\end{array}$ & Total \\
\hline$N$ & 32 & 35 & 36 & 103 \\
\hline \multicolumn{5}{|l|}{ Olives } \\
\hline Farms with terraces & 32.0 & 15.0 & 36.0 & 83.0 \\
\hline Total terraced area (ha) & 182.9 & 33.0 & 157.3 & 373.2 \\
\hline Terraced area $\%$ of total area & 100.0 & 84.4 & 100 & 98.4 \\
\hline \multicolumn{5}{|l|}{ Grazing lands } \\
\hline Farms with terraces & 1.0 & 21.0 & 5.0 & 27.0 \\
\hline Total terraced area (ha) & 1.0 & 359.3 & 18.8 & 379.1 \\
\hline Terraced area $\%$ of total area & 100.0 & 70.7 & 70.1 & 70.8 \\
\hline \multicolumn{5}{|l|}{ Tree crops } \\
\hline Farms with terraces & 9.0 & & 1.0 & 10.0 \\
\hline Total terraced area (ha) & 24.1 & & 0.7 & 24.8 \\
\hline Terraced area $\%$ of total area & 62.9 & & 100.0 & 59.6 \\
\hline \multicolumn{5}{|l|}{ Garden crops } \\
\hline Farms with terraces & 4.0 & 6.0 & 7.0 & 17.0 \\
\hline Total terraced area (ha) & 1.0 & 1.3 & 1.8 & 4.1 \\
\hline Terraced area $\%$ of total area & 25.0 & 48.1 & 43.9 & 38.0 \\
\hline \multicolumn{5}{|l|}{ Arable crops } \\
\hline Farms with terraces & & 3.0 & 1.0 & 4.0 \\
\hline Total terraced area (ha) & & 3.1 & 2.0 & 5.1 \\
\hline Terraced area $\%$ of total area & & 41.9 & 100.0 & 50.0 \\
\hline \multicolumn{5}{|l|}{ Vineyards } \\
\hline Farms with terraces & 1.0 & 3.0 & 2.0 & 6.0 \\
\hline Total terraced area (ha) & 0.4 & 1.3 & 1.1 & 2.8 \\
\hline Terraced area $\%$ of total area & 100.0 & 92.9 & 57.9 & 75.7 \\
\hline
\end{tabular}

market values. At the same time, abandoned olive fields are undesirable and there seems to be a certain degree of social disapproval for those that do not keep their fields clean and cultivated. Unsurprisingly, we find that the quality of terraces is not correlated with the age of the farmer or family income, and neither is it related to farm household groups. Rather, it seems to be related to when farmers have last maintained them.

Most of the respondents (74\%) affirmed that they had maintained their terraces in olive plantations in the past, but this can mean the 1960 s or the 1970 s $(1.3 \%$ and $4 \%$ respectively of those who had maintained their terraces), but most $(71 \%)$ reported that they had maintained them after 2000. Terraces reported as collapsed had been maintained in the 1980s or not maintained at all. Maintenance of terraces of other land uses was not so common and it was reported in the 1940s or the 1950s for some cases. The exception of grazing lands should be noted where $78 \%$ declared that they had maintained their terraces in the past, out of which $38 \%$ after 2000 .

More than half $(54 \%)$ of the respondents declared that they can build and maintain terraces themselves, and $60 \%$ of those who have maintained them said that they had done true that farmers have more reasons to maintain terraces olive fields, as neglected, abandoned fields have lower 
so themselves. Regarding maintenance and farm household group for olive plantations, the "hobby" group was the one that had maintained terraces less often $(64 \%$ of the cases, compared to $87 \%$ in the "professionals" and $76 \%$ in the "semi-professional" group).

\section{Land use changes}

The land use changes that were recorded are categorized into three types of change: (1) abandonment; (2) clearing; and (3) change of cultivation. Abandonment refers to the stopping of all cultivation practices followed by intrusion of shrubs or forest and therefore to the conversion of a lowinput traditional plantation to a neglected and eventually an abandoned one or of a cultivated arable field on terraces to a grazing land (Figs. 2, 3). Clearing refers to the conversion of natural or semi-natural habitats (including abandoned land) to cultivated or grazing land, here from abandoned to low-input traditional plantations or to grazing lands (but not to cultivated arable fields on terraces as arable cultivation on terraces is rare today). Change of cultivation refers to the conversion of cultivated land uses to other cultivated ones. Housing is not encountered here, as the settlements are away from the capital or from coastal and tourist areas where housing pressures are strong.

Overall, abandonment was by far the most common land use change for the farms of the sample: 20 farm households (19\% of the total) reported at least one case of abandonment. The total number of cases reported was 26 , as six farm households reported abandonment of more than one field (Table 6, one household reported three cases and five reported two cases). Some of these cases were old (44\% took place in the 1950s and 1960s) and a few very recent, but the general belief that recent abandonment is gradually increasing is not supported by the findings, at least for the farmers of the sample who live permanently in the settlements. ${ }^{2}$ Reasons given by the farmers for abandonment revolved around the economics of the farm, declaring that the cultivation of the abandoned field was no longer financially profitable. Other reasons offered included poor health or family problems. The abandoned terraced lands included olive plantations and arable lands, usually grazed after abandonment with destructive impacts on terraces, as abandonment involves the collapse of terraces in the $88 \%$ of the cases abandoned.

Clearing of scrubland was reported by 10 farm households (9.8\% of the total), but it seems that it was a practice that stopped after the 1980s, as no clearing was reported

\footnotetext{
2 The percentage of abandoned terraced plantations is estimated at roughly $50 \%$ of the total terraced plantations with the use of air photo interpretation, according to Dalaka and Petanidou (2006); the difference with the reported abandonment could lie in the fact that many abandoned fields are owned by absentees.
}

since. Economic reasons dominated completely the views of farmers here also, with olive plantations being the most common land use involved in clearing, usually from an abandoned grazing land. It is a land use change that created or maintained terraces in the fields $(90 \%$ of those that reported clearing also claim making new terraces), which implies that the building of terraces was still practiced until at least the 1980s, considering that in an already heavily terraced landscape, new terraces could be build only on recently cleared land to support the new cultivation or recultivate a formerly abandoned and forested field.

Change of cultivation was reported by 13 farm households $(12.6 \%$ of the total). It is an active process throughout the last eight decades, involving all changes in all farm land uses (i.e., olive plantations, grazing lands, tree, and arable and garden crops) in approximately equal shares. Economic reasons dominate the reasoning of farmers as they make these changes. The impacts of cultivation changes on terraces were mixed according to what the farmers said: $61 \%$ reported that there was no impact on terraces while $23 \%$ that they were destroyed.

Regarding land use changes and farm household groups, the findings present a clear distinction (Table 6). For "professional" farm households, the changes reported were few $(N=3)$, with no cultivation changes and the abandonment cases taking place in the 1980s. "Semiprofessionals" have made more changes $(N=16)$, of comparable frequencies, but most have been made in the past. Finally, "hobby" farm households reported most changes ( $N=30,61 \%$ of all cases). Most of these involved abandonment of at least one field and chronologically span over many decades, but many were recent, indicating that within this farm group abandonment is an option. Almost all clearings and cultivation changes referred to old changes (in the 1960s for clearing and in the 1970s for cultivation change). It appears therefore, that "hobby" farm households can be active in terms of cultivation practices, but are more susceptible to land use changes, which in recent years are mostly for the abandonment of fields. Regarding land use changes and land use zones, in the eastern (olives) zone, no clearing was reported and changes were overall few. In the intermediate zone, all changes had comparable frequencies, while in the western zone (grazing lands) most of the abandonment had taken place.

Views and attitudes of farmers

The landscape of their area was very dear to respondents, for a number of reasons: most said that because they were born and raised in this landscape and have not lived in another area to compare, they considered this landscape a part of their everyday life and their identity. Terraces were considered as a vital and integral part of this landscape by 
Table 6 Land use changes for the farms of the sample for farm household groups and land use zone

\begin{tabular}{|c|c|c|c|c|}
\hline & Abandonment & Clearing & Cultivation change & Total \\
\hline $\begin{array}{l}\text { Number of farm households that reported } \\
\text { at least one change }\end{array}$ & 20 & 10 & 13 & 39 \\
\hline Number of changes & 26 & 10 & 13 & 49 \\
\hline$\%$ & 53.1 & 20.4 & 26.5 & 100.0 \\
\hline Eastern (olives) $(N=32)$ & $6(23.1 \%)$ & & $5(38.5 \%)$ & $11(22.4 \%)$ \\
\hline Western (grazing lands) $(N=35)$ & $16(61.5 \%)$ & $5(50.0 \%)$ & $4(30.8 \%)$ & $25(51.0 \%)$ \\
\hline Central (intermediate) $(N=36)$ & $4(15.4 \%)$ & $5(50.0 \%)$ & $4(30.8 \%)$ & $13(26.5 \%)$ \\
\hline Total $(N=103)$ & $26(100.0 \%)$ & $10(100.0 \%)$ & $13(100.0 \%)$ & $49(100.0 \%)$ \\
\hline Professionals $(N=15)$ & $2(7.7 \%)$ & $1(10.0 \%)$ & & $3(6.1 \%)$ \\
\hline Semi-professionals $(N=46)$ & $7(26.9 \%)$ & $4(40.0 \%)$ & $5(38.5 \%)$ & $16(32.7 \%)$ \\
\hline Hobbists $(N=42)$ & $17(65.4 \%)$ & $5(50.0 \%)$ & $8(61.5 \%)$ & $30(61.2 \%)$ \\
\hline Total $(N=103)$ & $26(100.0 \%)$ & $10(100.0 \%)$ & $13(100.0 \%)$ & $49(100.0 \%)$ \\
\hline
\end{tabular}

Source: Authors' research findings and calculations, no statistically significant differences of type of land use change and location of the farms or farm household groups

almost all of the respondents (96\%). Most pointed to the functional value of terraces for cultivation and not only their aesthetic and symbolic value. If they are maintained and the understory is cleared from shrubs, fields were considered as very "orderly" and "tidy" and a sign of good "farm-ship," a hard working farmer who takes good care of his land.

This landscape is now changing to them due to abandonment and the collapsing of its elements. For this apparent change in the agricultural landscape of the area $(77 \%$ claimed that the landscape was different in the past), most farmers blamed out migration and abandonment of farming. Now the "fields are empty" according to a farmer in Kato Tritos and "abandonment shows in the fields, they are not in order and tidy, there are shrubs and no signs that people pass through there." According to the respondents, this outmigration started in the 1960s, to Athens and in general to continental Greece or abroad, and continued in the 1990s towards Mytilini. They justified the out migrants as olive cultivation is not profitable enough nowadays and they have to face increased labor costs and declining olive oil prices.

The future was painted in dark colors, as the young have no motives to become farmers and only sheep husbandry is still profitable due to subsidies, but very "hard work." For terraces, things look even darker to them, as "very few now take care of their farms and their setia [terraces in local dialect], in the future... the village and the fields will be deserted" (farmer in Agra). There were no differences for farmer characteristics or farm household groups.

\section{Discussion}

The approach followed here employs the concept of farming systems to describe and understand processes of landscape change in micro scale-that of farmers-for terraced cultivations on Lesvos Island. Farming systems link the scale of farmers' practices at the farm level with changes at the landscape level. In this particular case study, we assumed that different degrees of dependence from farming for incomes and occupation of the farm household members can result in different practices, different land use changes, and different management of the terraced landscape elements. This is a common approach: Meert et al. (2005, pp. 3-4) produce six different "pathways" based on farm employment in a "natural order" of reduced "agriculture character" of the farms. Lobley and Potter (2004, p. 505) present a "restructuring" farm typology for four types of farms: from full time to lifestyle farmers, with the dependence of family income from farm incomes being the criterion used.

According to this dependence on farming incomes, farm households were categorized in three groups: "professional," "semi-professional," and "hobby." This categorization has yielded some differences concerning farm size and animal husbandry ("professional" farm households are larger on average and have larger sheep herds), but not regarding the dominance of olive plantations. It has not yielded significant differences regarding the cultivation practices on terraced olive plantations, where almost all farm households are active. Similarly, it has not yielded differences in the management of the dominant landscape element, terraces. On the contrary, differences concerning land use changes at the farm level are found, as "hobby" farm households have abandoned more fields than the rest of the groups.

Reasons behind these similarities despite actual differences in income and occupation are related with two different factors. The first refers to the special case of olive plantations. Olive plantations can be managed with 
relatively few practices and with the labor of family members. Even in "hobby" farm households, cultivation practices other than picking of the olives can be managed by an old farmer with a lot of time to spare, or by more than one member of the household or the family at leisure (weekends, afternoons) or with the use of workers (immigrants in the last two decades). The second reason refers to the symbolic value of olive plantations and their appearance. In the views of farmers, fields are considered as "orderly" or "tidy" when the understory is managed and not encroached by shrubs, the terraces are maintained, and the trees are pruned. Farmers feel pressure (family and social) to keep their fields in this state, even if they have to spend rather than earn money. A common response of farmers on the island to questions on olive fields management is that "we have found them like this [i.e., cultivated and managed] and will hand them over to our children like this," in a view that regards the fields not as assets, but as family capital and something you have to take care for the next generation. It seems therefore that mostly for personal and cultural reasons some practices, especially the maintenance of terraces, are still applied at some extent. Here the model of economic reasoning behind decisions that change or conserve landscapes is not applied. Of course, farmers who are getting old or simply cannot afford to manage all of their fields, abandon or sell their land, but not in the extent that they would do for other land uses.

Regarding small-scale landscape change, two different trends were observed in the farms of the sample. First, in most of the olive fields the different cultivation practices result in the same landscape, that of low-input traditional plantations, regardless of land use zone or farm household group. The same is true for grazing lands as well, as there are no significant differences to practices and landscapes according to land use zone or farm household group. Second, at the same time, some of the fields are abandoned, especially from farms of "hobby" farm households. The "translation" of these small-scale dynamics to large-scale landscape change is not straightforward, as most of these findings are restricted to farmers that still live in the case study settlements. These farmers are a minority considering those who have left the particular settlements for good in the past (and thus are not included in the sample), or those that live in the capital town of the island and visit periodically to help aged parents of relatives or manage their farms from a distance (and are not included in the sample as well). Therefore, the sample is incomplete to map the overall landscape change, as it omits certain farm households that were active during the making of this landscape and are not active now. The sample however expresses very well the people who have stayed behind and continued to farm, abandoning certain fields and managing others.
The effects of policies on this farming system and its variations are diverse. The Common Agricultural Policy of the EU has affected farming on Lesvos in the past in mixed ways: subsides in the 1980s and part of the 1990s can be held partially responsible for increasing the number of grazing animals, as they not linked with grazing lands (this has changed under the new CAP regime). At the same time, the LFA scheme was proven successful as a (small) extra income to farm households. The fact that it is not paid to aged farmers though (over 65 years old) is limiting the pool of farmers it can draw on. This is true for the rest of the rural development policies as well (the young farmers' scheme, the early retirement scheme, food processing investments, etc.) with the exception of investment aid that is very successful (as in the rest of Greece), but provides limited actual assistance in the particular setting. ${ }^{3}$

Agri-environmental measures were proven helpful only for organic farming and more recently for organic animal husbandry. A recent measure for the reconstruction of terraces has met some success on the island, but its scope and funding is very limited and therefore its actual impact on the quality of terraces minimal. ${ }^{4}$ Finally, the new regime of the CAP for olive oil subsidies (effective from 2007) is expected to bring forward some changes, but it is uncertain towards which direction. The fact that for olives there is a full decoupling of subsidy and production may cause greater negligence.

According to our experience and the views of the farmers themselves, the most important issue is outmigration. Even though the presence of immigrant workers (mostly Albanians during the 1990s and early 2000s and today Bulgarians, Kurds and others except Albanians) allows even very aged farmers to manage their fields and "frees" members of the household and the family from working in the olives, the absence of younger people living and working in the fields in some of the settlements of the research is striking. Since the wider socioeconomic changes that have caused this development (reduced incomes from farming, reduced social acceptance of farming as a

\footnotetext{
3 The particular measure supports farmers to buy new equipment, build or rebuild farm infrastructure, etc. It is a valuable tool for animal husbandry and for arable farming, but for the olives of the island (old trees, mountainous, with terraces, with no irrigation water) it provides little actual help.

4 The particular measure funds the reconstruction of terraces, according to some technical guidelines, but the amounts it provides cover partly the actual reconstruction work and there are two limitations: (1) the sum is given over a five-year period and theoretically the reconstruction must be divided in each of these years (as in all agri-environmental measures), which is practically very difficult; (2) beneficiaries of another agri-environmental measure receive a small fraction of the sum, as there is an upper limit to the amount a farmer can receive annually from such measures, which practically excludes all organic farmers. For more details and a thorough analysis, see Kizos et al. (forthcoming).
} 
"professional" occupation for ones' children, and the movement of young people to the island's urban center) seem irreversible for the moment, farming is expected to decline as a "professional" activity and be kept as a secondary or "hobby" occupation. The link with the settlements is still strong for most of the out-migrants, and this is reflected in the census results. Therefore, villages may not be deserted completely as some respondents fear, but it seems that farming enters this picture only as a "leisurely" activity or something done with workers. But, abandonment and negligence of management practices are more probable for these "hobby" farmers. These developments endanger some environmentally valuable farming practices and change the rich cultural landscape.

Therefore, the assumption that different degrees of dependence from farming results in different practices, land use changes, and management of the terraced landscape elements is only partially supported by the findings. "Hobby" farm households are more likely to abandon their fields than "professional" ones and keep smaller farms, but are active and manage their terraces in the fields that they have not abandoned. Out-migration and the aging farming population are also parts of the picture and should be included in an explanation of farm and landscape change in the area.

\section{Conclusion}

The example presented here is one of a slow and gradual change of a rich cultural landscape due to the changes of farmers' practices and therefore farming systems. The fact that this particular landscape includes mostly tree cultivation with little "modern" practices delays the rate of change. Nevertheless, it seems that this whole farming system is unstable, due to the aging farming population. Regarding the particular landscape characteristic discussed here, terraces, policies for their reconstruction or maintenance are at best marginal and their collapse sometime in the future is expected to have a major cultural, ecological, and physical impact upon the landscape. The findings indicate that this gradual ceasing of practices that include their maintenance today appears irreversible and puts the whole landscape at risk.

Thus, the concept of farming systems has assisted the analysis of the findings and it seems that in the context of small/farm landscape change it can provide a useful framework for understanding the practices of farm households and their differences over time and space. Especially for landscape characteristics such as terraces, it can point to the reasons of their maintenance or neglect and provide possible policy responses to mitigate these changes. Finally, the particular case study indicates that when such management practices are considered, a more complex decision making model than just plain economic reasoning is necessary, as it is only one aspect of the overall process for farm households. This is a lesson in conceptualizing change and planning for or against it.

Acknowledgments This study has been supported by the EPEAEK II-PYTHAGORAS Programme (Measure 2.6, action 2.6.1, category 2.6.1.) of the Greek Ministry of Education, entitled: "The terraced landscape of Lesvos: Mapping land use change and studying the biological diversity dynamics throughout all successional stages." We thank Anastasia Vatsou and Varvara Vounatsou for their contributions during the fieldwork.

\section{References}

Bakker, M.M., G. Govers, C. Kosmas, V. Vanacker, K. van Oost, and M. Rounsevell. 2005. Soil erosion as a driver of land-use change. Agriculture Ecosystems \& Environment 105(3): 467-481.

Blanchemanche, P. 1990. Batisseurs de paysages: Terrassement, epierrement et petite hydraulique agricoles en Europe XVII-XIX siecles. Paris: Maison des Sciences de l'Homme.

Busck, A.G. 2002. Farmers' landscape decisions: Relationships between farmers' values and landscape practices. Sociologia Ruralis 42: 233-249.

Dalaka, A., and T. Petanidou. 2006. O rolos tis voskisis sta anavathmidomena agro-oikosistimata tis Lesvou (The role of grazing in terraced agro-ecosystems of Lesvos; with English summary). In Range science of xerothermic areas. Proceedings of the 5th Panhellenic Rangeland Congress, ed. V. Papanastasis and Z.M. Parisi, 51-7. Heraclion, Crete 1-3 November 2006.

Damianakos, S. 2002. Apo ton horiko ston agroti: H Ellhkini agrotiki koinoia apenanti sti pagosmiopoiisi (From peasant to farmer: Greek rural society towards globalization). Athens: Exantas and EKKE.

ESYE. 2003. Apotelesmata apografis georgias-ktinotrofias 20002001 (Agriculture and animal husbandry census results). http://www.statistics.gr. Accessed 1 Dec 2008.

Farina, A. 2006. Principles and methods in landscape ecology: Towards a science of landscape. Berlin: Springer.

Fu, B.J., C.X. Hu, L.D. Chen, O. Honnay, and H. Gulinck. 2006. Evaluating change in agricultural landscape pattern between 1980 and 2000 in the Loess hilly region of Ansai County, China. Agriculture, Ecosystems \& Environment 114(2-4): 387-396.

Fleskens, L., and J. de Graaff, eds. 2008. A sustainable future for olive production on sloping land, the future of olive plantation systems on sloping and mountainous land, and scenarios for production and natural resources conservation. Journal of Environmental Management 89 (2): 73-142.

Gallart, F., P. Llorens, and J. Latron. 1994. Studying the role of old agricultural terraces on runoff generation in a small Mediterranean mountainous basin. Journal of Hydrology 159: 291-303.

Grenon, M., and M. Batisse. 1989. Futures for the Mediterranean basin: The blue plan. Paris: UNEP.

Grove, A.T., and O. Rackham. 2002. The nature of Mediterranean Europe: An ecological history. New Haven: Yale University Press.

Hill, J., P. Hostert, G. Tsiourlis, P. Kasapidis, T. Udelhoven, and C. Diemer. 1998. Monitoring 20 years of increased grazing impact on the Greek island of Crete with earth observation satellites. Journal of Arid Environments 39(2): 165-178.

Kizos, T., and M. Koulouri. 2006. Agricultural landscape dynamics in the Mediterranean: Lesvos Greece case study using evidence 
from the last three centuries. Environmental Science and Policy 9: 330-342.

Kizos, T., and M. Koulouri. Forthcoming. Same land cover, same land use at the large scale, different landscapes at the small scale: Landscape change in olive plantations on Lesvos Island, Greece. Landscape Research.

Kizos, T., M. Koulouri, H. Vakoufaris, and M. Psarrou. Forthcoming. Preserving characteristics of the agricultural landscape through agri-environmental policies: The case of cultivation terraces in Greece. Landscape Research.

Kizos, T., and I. Spilanis. 2004. The transformation of landscape: Modeling policy and social impacts on the agricultural landscape of Lesvos. Natural Resource Modelling 17: 321-358.

Kristensen, S.P. 1999. Agricultural land and landscape changes in Rostrup, Denmark: Processes of intensification and extensification. Landscape and Urban Planning 46: 117-123.

Kristensen, L.S., C. Thenail, and S.P. Kristensen. 2004. Landscape changes in agrarian landscapes in the 1990s: The interaction between farmers and the farmed landscape. A case study from Jutland, Denmark. Journal of Environmental Management 71: 231-244.

Lobley, M., and C. Potter. 2004. Agricultural change and restructuring: Recent evidence from a survey of agricultural households in England. Journal of Rural Studies 20: 499-510.

Long, H., G. Tang, X. Li, and G.K. Heilig. 2007. Socio-economic driving forces of land-use change in Kunshan, the Yangtze River Delta economic area of China. Journal of Environmental Management 83(3): 351-364.

Marcucci, D.J. 2000. Landscape history as a planning tool. Landscape and Urban Planning 49: 67-81.

Meert, H., G. Van Huylenbroeck, T. Vernimmen, M. Bourgeois, and E. Van Hecke. 2005. Farm household survival strategies and diversification on marginal farms. Journal of Rural Studies 21(1): 81-97.

Netting, R.M. 1993. Smallholders, householders: Farm families and the ecology of intensive, sustainable agriculture. Stanford: Stanford University Press.

Olarieta, J.R., F.L. Rodriguez-Valle, and E. Tello. 2008. Preserving and destroying soils, transforming landscapes: Soils and land-use changes in the Valles County (Catalunya, Spain) 1853-2004. Land Use Policy 25(4): 474-484.

Ostwald, M., and D. Chen. 2006. Land-use change: Impacts of climate variations and policies among small-scale farmers in the Loess Plateau, China. Land Use Policy 23(4): 361-371.

Petanidou, T., T. Kizos, and N. Soulakellis. 2008. Socioeconomic dimensions of the agricultural landscape change in the Mediterranean: The case of the abandonment of cultivation terraces on Nisyros Island, Greece. Environmental Management 41: 250266.

Quetier, F., P. Marty, and J. Lepart. 2005. Farmers' management practices and land use on an agropastoral landscape: Roquefort cheese production as a driver of change. Agricultural Systems 84: 171-193.

Rao, K.S., and R. Pant. 2001. Land use dynamics and landscape change pattern in a typical micro watershed in the mid elevation zone of central Himalaya, India. Agriculture, Ecosystems, and Environment 86: 113-123.

Stroosnijder, L., M.I. Mansinho, and A.M. Palese. 2008. OLIVERO: The project analysing the future of olive production systems on sloping land in the Mediterranean basin. Journal of Environmental Management Volume 89(2): 75-85.

Thomaidou, A., and K. Koutsobilis. 2004. Multispectral classification of a Landsat TM image via QuickBird images: Mapping of olive plantations on Lesvos Island and estimation of the number of olive trees (in Greek). Lesvos: Graduation Project, Department of Geography, University of the Aegean.

Van-Camp, L., B. Bujarrabal, A.-R. Gentile, R.J.A. Jones, L. Montanarella, C. Olazabal, and S.-K. Selvaradjou. 2004. Reports of the Technical Working Groups established under the Thematic Strategy for Soil Protection, EUR 21319 EN/2. Luxembourg: Office for Official Publications of the European Communities.

Van der Ploeg, J.D. 1992. Styles of farming: An introductory note on concepts and methodology. In Born from within: Practice and perspectives of endogenous rural development, ed. A. Long, and J.D. van der Ploeg, 7-30. Wagenigen: Van Gorcum.

Varisco, D.M. 1991. The future of terrace farming in Yemen: A development dilemma. Agriculture and Human Values 8(1-2): 166-172.

\section{Author Biographies}

Thanasis Kizos is an agronomist and has a $\mathrm{PhD}$ in environmental science. He is Lecturer in Rural Geography in the Department of Geography, University of the Aegean. His research and publications concern rural landscape change and rural development, with a focus on issues of rural livelihoods, farm household dynamics, and micro(farm)-scale landscape change.

Anastasia Dalaka is a biologist with $\mathrm{PhD}$ in ecology. She teaches in the Department of Geography, University of the Aegean. Her scientific interests are plant ecology, biodiversity, Mediterranean (natural and semi-natural) ecosystems, and man-made landscapes.

Theodora Petanidou has a $\mathrm{PhD}$ in Ecology and is Associate Professor of Environmental Geography in the Department of Geography, University of the Aegean. Her research interests are ecogeography of the Mediterranean (with special focus on natural resources, man-made landscapes, and land use change), biogeography, and pollination ecology. 